\title{
Analysis of serum magnesium ions in dogs exposed to external stress: A pilot study
}

\author{
Izumi Ando ${ }^{1}$, Kaoru Karasawa ${ }^{1,2}$, Shinichi Yokota ${ }^{3}$, Takao Shioya ${ }^{4}$, Hiroshi Matsuda ${ }^{1,3}$ and Akane Tanaka ${ }^{1,2, *}$ \\ ${ }^{I}$ Cooperative Major in Advanced Health Science, Graduate School of Bio-Applications and System Engineering, \\ Tokyo University of Agriculture and Technology, Tokyo 183-8509, Japan \\ ${ }^{2}$ Laboratory of Comparative Animal Medicine, Division of Animal Life Science, Institute of Agriculture, Tokyo \\ University of Agriculture and Technology, Tokyo 183-8509, Japan \\ ${ }^{3}$ Laboratory of Veterinary Molecular Pathology and Therapeutics, Division of Animal Life Science, Institute of \\ Agriculture, Tokyo University of Agriculture and Technology, Tokyo 183-8509, Japan \\ ${ }^{4}$ The Eye Mate Inc., Tokyo 177-0051, Japan
}

\begin{abstract}
Magnesium ions $\left(\mathrm{Mg}^{2+}\right)$ are essential for various enzymatic reactions in the body associated with energy production and activation of the muscles and nerves. $\mathrm{Mg}^{2+}$ is also involved in blood pressure regulation, maintenance of body temperature, and glucose metabolism. Although various factors including foods and physical conditions have been reported to change serum $\mathrm{Mg}^{2+}$ status in humans, serum $\mathrm{Mg}^{2+}$ in dogs exposed to external stress has been unclear. In this study, we examined serum levels of $\mathrm{Mg}^{2+}$ in dogs at different conditions using the guide dog candidates for the blind. Serum $\mathrm{Mg}^{2+}$ was decreased in winter and increased in summer. Guide dog candidates in an elementary class of the training showed markedly lower levels of serum $\mathrm{Mg}^{2+}$, compared with that of dogs in an advanced class. When healthy adult dogs were subjected to forced exercise using a treadmill, a significant reduction in serum $\mathrm{Mg}^{2+}$ levels was observed, particularly in winter. These findings suggest that serum levels of $\mathrm{Mg}^{2+}$ may be influenced by weather fluctuation such as air temperature, nervousness in unaccustomed situations, age, and physical stress induced by exercise. The results indicate that $\mathrm{Mg}^{2+}$ supplementation should be considered for working dogs, dogs moving or traveling to a new environment, and dogs during winter.
\end{abstract}

Keywords: Exercise, Guide dogs, Seasonality, Serum magnesium ions, Training.

\section{Introduction}

Magnesium ions $\left(\mathrm{Mg}^{2+}\right)$ are one of the essential minerals necessary to maintain life. Most $\mathrm{Mg}^{2+}$ is stored in the cells of organs and tissues, particularly in the bones and teeth. Small amounts of $\mathrm{Mg}^{2+}$ are present in extracellular spaces, where $\mathrm{Mg}^{2+}$ binds with either proteins or anions. $\mathrm{Mg}^{2+}$ is needed to generate energy by assisting in the reaction of various enzymes with $\mathrm{Mg}^{2+}$ binding sites in their active region (Cowan, 2002). $\mathrm{Mg}^{2+}$ is necessary for the synthesis of proteins, energy metabolism (Pfeiffer and Barnes, 1981; He et al., 2006), contraction of the muscles (Altura and Altura, 1981), blood pressure regulation (Resnick et al., 2000; He et al., 2005), and modulating blood glucose levels (Dominguez et al., 1998; Singh et al., 1998), as well as a considerable number of enzymatic reactions within the body (Cowan, 2002). Lack of $\mathrm{Mg}^{2+}$ induces deterioration in energy production, leading to fatigue (Lukaski and Nielsen, 2002). $\mathrm{Mg}^{2+}$ deficiency also causes poor concentration, chronic fatigue, loss of appetite, and cardiovascular abnormalities in humans (Bohl and Volpe, 2002). Concentration of $\mathrm{Mg}^{2+}$ in blood is regulated by the interaction of several hormones, including, noradrenaline, parathyroid hormone, glucagon, and cortisol (Soria et al., 2014). Intravenous injection of catecholamine induced a marked increase of $\mathrm{Mg}^{2+}$ excretion in the urine (Rayssiguier, 1977; Joborn et al., 1985), suggesting catecholamine may reduce blood $\mathrm{Mg}^{2+}$ levels.

In humans, abnormalities in serum $\mathrm{Mg}^{2+}$ levels have been reported in various diseases (Elin, 1988; Rude and Gruber, 2004; Sinert et al., 2005; Baltaci et al., 2013), and, interestingly, the morbidity of these diseases has been reported to correlate with $\mathrm{Mg}^{2+}$ intake (Elin, 1988; Singh et al., 1997; Eby and Eby, 2006). However, the dietary intake of $\mathrm{Mg}^{2+}$ reduces with age (Bazzarre et al., 1993; Durlach et al., 1993; Tucker et al., 1999). The market for $\mathrm{Mg}^{2+}$ supplements has expanded for prophylactic amelioration of lifestyle related diseases (Seelig and Altura, 1997). In addition, $\mathrm{Mg}^{2+}$ supplementation in training athletes has also increased (Haymes, 1991). Moreover, reduction in $\mathrm{Mg}^{2+}$ intake has been reported to be associated with severity of depression and anxiety in community-dwelling adults, and administration of $\mathrm{Mg}^{2+}$ to patients improved their conditions (Jacka et al., 2009). 
Changes in the serum $\mathrm{Mg}^{2+}$ levels of dogs have not been fully explored. The aim of this study was to analyze changes in serum $\mathrm{Mg}^{2+}$ levels of dogs before and after a training or exercise load.

\section{Animals}

\section{Materials and Methods}

All animal experiments complied with the standards specified in the guidelines of the University Animal Care and Use Committee of the Tokyo University of Agriculture and Technology as well as the guidelines for the use of laboratory animals provided by the Science Council of Japan. The procedures conducted were approved by the University Animal Care and Use Committee of the Tokyo University of Agriculture and Technology (No. 27-62; July, 27, 2015). For blood collection from guide dog candidates, all procedures were informed approved by The Eye Mate Inc. (Tokyo, Japan). Young Labrador retrievers (aged from 17 to 35 months, mean age was $23 \pm 0.8$ months old.) that had been selected as candidates for guide dogs for the blind were subjected to the measurement of serum $\mathrm{Mg}^{2+}$ in the experiment 1 (12 dogs) and $2(24 \mathrm{dogs})$. They were housed in individual cages in a room illuminated daily from 6:00-21:00 with a temperature of $15-25 \pm 3^{\circ} \mathrm{C}$. The room temperature of the kennel was set according to that of the outside, because the training of the dog was carried out in city areas. They were fed with appropriate food once a day at 7:00 and were given water ad libitum. They were all neutered and belonged to The Eye Mate Inc. The Eye Mate Inc. has the longest history of dog training in Japan and provides the largest number of well-trained guide dogs to the blind. Healthy Labrador retrievers that worked as guide dogs for the blind (mean age was $6.9 \pm 0.4$ years old, 6 neutered males and 8 neutered females) were subjected to the measurement of serum $\mathrm{Mg}^{2+}$ in the experiment 2 (14 dogs). They were all neutered and belonged to their user. They were fed by their users. Three of them were fed in the morning and 11 of them were fed in the night. All the guide dog candidates and guide dogs were fed with the same food.

In the experiment 3 , we used 6 laboratory dogs. They were housed in individual cages in a room illuminated daily from 7:00-19:00 with a temperature of $21 \pm 4^{\circ} \mathrm{C}$. They were fed with appropriate food once a day at 19:00 and were given water ad libitum. They were allowed to take a walk or free exercise at the outside of their facilities with animal care staffs for 30-60 min in one day for their welfare, except the day of the experiment. They were all neutered, fed with the same food, and managed in the same circumstances.

Foods supplied to dogs used in the current study are shown in Table 1. Natural Harvest Maintenance (13-15 $\mathrm{g} / \mathrm{kg}$ body weight/day) (Vanguard International Foods Co., Chiba, Japan) was given to guide dog candidates and guide dogs for the blind, and Acana Pacifica for dogs (15-20 g/kg body weight/day) (Champion Pet Foods Ltd., AB, Canada) was given to laboratory dogs. Dogs used in each experiment

In the experiment 1,12 guide dog candidates in the advanced classes (aged from 21 to 35 months) were used to confirm seasonal changes of serum $\mathrm{Mg}^{2+}$ levels. The advanced class is a final stage of their training. Blood samples collected in January, May, and August from different dogs in the advanced class at each month, and serum $\mathrm{Mg}^{2+}$ levels were analyzed. Each group was consisted of 4 dogs (1 neutered male and 3 neutered females). In Eye Mate Inc., 4 dogs finish their trainings every month and start working as mature guide dogs for the blind.

In the experiment 2 , the total of 24 guide dog candidates and 14 working guide dogs were used to measure serum $\mathrm{Mg}^{2+}$ levels. Training phases of those candidates are divided into three classes as described below. The elementary training class included dogs that could walk with their instructor on their leads for 10-15 min. The intermediate class included dogs that could wear harnesses to walk under the simple commands of their instructor on an empty street for 20-30 min. The advanced class included dogs that could wear harnesses to walk under the commands of their instructor on a busy street for 40-50 min. Six dogs (the mean age was $19.8 \pm 0.8$ months old, 1 neutered male and 5 neutered females) in the elementary class, 10 dogs (the mean age was $21.1 \pm 0.9$ months old, 4 neutered males and 6 neutered females) in the intermediate class, and 8 dogs (the mean age was $26.5 \pm 1.5$ months old, 2 neutered males and 6 neutered females) in the advanced class were subjected to the study. Fourteen healthy Labrador retrievers that worked as guide dogs for the blind (mean age was $6.9 \pm 0.4$ years old, 6 neutered males and 8 neutered females) were subjected to the measurement of serum $\mathrm{Mg}^{2+}$ in the experiment 2 under the informed consent of their owners as adult controls.

In the experiment 3 , we used a treadmill to test the effects of forced exercise. In this experiment, three healthy mixed breed dogs (aged from 5 to 6 years), one Beagle dog (6 years old), one Jack Russell Terrier (6 years old) and one Miniature Dachshund (9 years old), belonging to the colony of our laboratory were used. They included 3 neutered males and 3 neutered females. Before and after the treadmill training performed in January and August, blood samples were collected. To assess the effects of forced exercise on serum $\mathrm{Mg}^{2+}$ levels, laboratory dogs undertook $20 \mathrm{~min}$ of physical exercise on a treadmill that was set at 3-6.5 $\mathrm{km} / \mathrm{h}$. The speed of the treadmill was set according to the physical ability of each dog.

\section{Blood sampling}

To investigate serum $\mathrm{Mg}^{2+}$ levels of dogs, guide dog candidates at different phases of training were examined. We collected blood samples from dogs in the 
elementary and intermediate classes on the first day of their training. We collected blood samples from dogs in the advanced class on the day that the training was completely over. Blood samples $(1.5 \mathrm{~mL} / \mathrm{dog})$ of laboratory dogs were collected at each time point of their exercise. Samples were taken from the cephalic vein by experienced veterinarians and were collected into serum-separator tubes (SST II; Becton, Dickinson $\&$ Co.). The tubes were allowed to stand for $30 \mathrm{~min}$ at room temperature and were then centrifuged for $10 \mathrm{~min}$ at $425 \mathrm{~g}$. Separated serum was collected and stored at $30^{\circ} \mathrm{C}$ until use.

\section{Measurement of serum $\mathbf{M g}^{2+}$ levels}

Serum $\mathrm{Mg}^{2+}$ was measured by the quantitative colorimetric determination method using the QuantiChrom Magnesium Assay Kit (DIMG-250; BioAssay Systems, Hayward, CA), according to the manufacturer's protocol. Using the assay kit, we can directly measure magnesium ions in serum samples without any pretreatment. All assays were performed in flat-bottom 96 well plates (Nunc PolySorp ${ }^{\circledR}$; Thermo Fisher Scientific, Inc., Tokyo, Japan). A calmagite dye used in the assay kit forms a colored complex specifically with magnesium ions. The absorbance values were measured at $500 \mathrm{~nm}$ using a micro plate reader (ImmunoMini (NJ-2300); BioTec, Suffolk, UK). Serum $\mathrm{Mg}^{2+}$ values were expressed as the mean of triplicate measurements.

\section{Measurement of plasma adrenaline and noradrenaline levels}

Previous studies have described that increase in blood levels of adrenaline might associate with of hypomagnesemia in humans and ewes (Rayssiguier, 1977; Joborn et al., 1985). Since exercise stress induces increase in blood catecholamine levels, we measured adrenalin and noradrenalin after exercise loads and tried to delineate possible association of those markers in blood $\mathrm{Mg}^{2+}$ levels. Plasma of each dog was isolated using EDTA-2Na and stored at $-30^{\circ} \mathrm{C}$ until use as described above. Plasma adrenaline and noradrenaline levels were measured by using the high-speed liquid chromatography systems (Shimadzu Corp., Kyoto, Japan) in SRL Inc. (Tokyo, Japan).

\section{Statistical analysis}

Data were analyzed using IBM SPSS Statistics ver. 22.0. In the experiment 1 , the comparison between three groups was analyzed using multiple comparisons with Bonferroni correction $(\mathrm{P}<0.05 / 3$ was estimated as a level of significance). In the experiment 2 , the comparison between four groups was analyzed using a one-way ANOVA and Dunnett test $(\mathrm{P}<0.05)$. In the experiment 3 , the influences of seasonal variation, and before and after the exercise load, were analyzed using a two-way ANOVA within-participant design ( $\mathrm{P}<$ 0.05). Serum $\mathrm{Mg}^{2+}$ levels were quoted as median and interquartile ranges in all figures.

\section{Results}

Experiment 1; Seasonality of serum $\mathrm{Mg}^{2+}$ levels

To examine the serum $\mathrm{Mg}^{2+}$ levels of dogs with very few individual differences due to their environments and foods, we used guide dog candidates with the agreement of The Eye Mate Inc., a Japanese public incorporated foundation that raises guide dogs. Since serum $\mathrm{Mg}^{2+}$ levels are influenced by temperature and the seasons in humans (Owaki et al., 1996), we first assessed seasonal variations of serum $\mathrm{Mg}^{2+}$ levels in dogs. We collected blood samples from the guide dog candidates in the advanced class in January (winter, average temperature for the last five years in Tokyo, Japan is $5.7^{\circ} \mathrm{C}$ ), May (spring, $19.4^{\circ} \mathrm{C}$ ), and August (summer, $28.6^{\circ} \mathrm{C}$ ). The serum $\mathrm{Mg}^{2+}$ levels of January, May, and August were $16.7 \pm 0.2 \mu \mathrm{g} / \mathrm{mL}$ (the median is $16.9 \mu \mathrm{g} / \mathrm{mL}$ ), $20.7 \pm 0.3 \mu \mathrm{g} / \mathrm{mL}$ (the median is 21.0 $\mu \mathrm{g} / \mathrm{mL}$ ), and $21.2 \pm 0.2 \mu \mathrm{g} / \mathrm{mL}$ (the median is 21.7 $\mu \mathrm{g} / \mathrm{mL}$ ), respectively (Fig. 1a). Serum $\mathrm{Mg}^{2+}$ levels of dogs in the advanced class were significantly lower in winter. On the other hand, serum $\mathrm{Mg}^{2+}$ levels increased in summer.

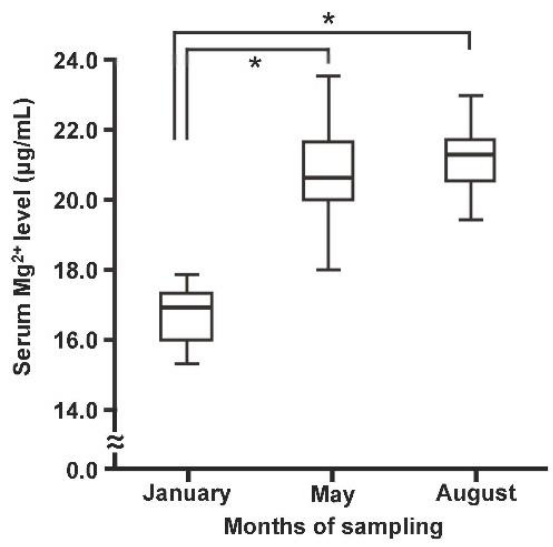

Fig. 1a. Seasonal variation in serum $\mathrm{Mg}^{2+}$ levels of guide dog candidates in the advanced class. The median values of serum $\mathrm{Mg}^{2+}$ levels are indicated by the bar within each box. The statistical significance of differences between the three groups was tested using Bonferroni correction. $n=4$ in each group. $(* \mathrm{P}<0.05)$.

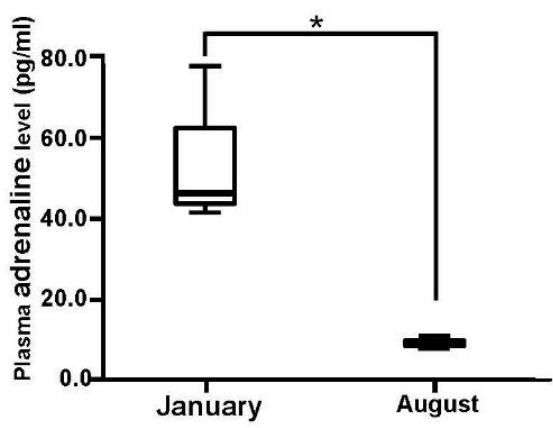

Fig. 1b. Seasonal variation in plasma adrenaline levels of guide dog candidates in the advanced class. The statistical significance of differences between January and August was tested using paired t-test. $\mathrm{n}=4$ in each group. $(* \mathrm{P}<0.05)$. 


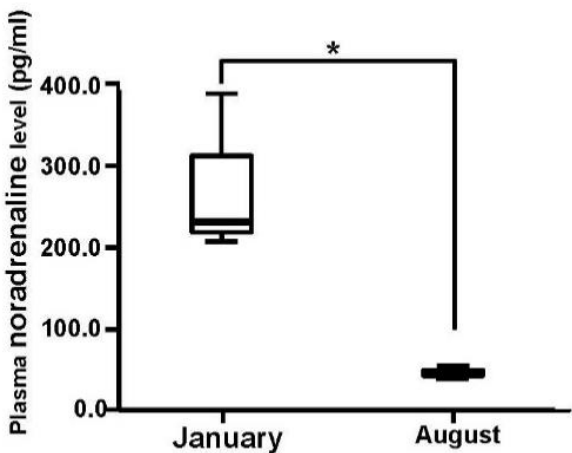

Fig. 1c. Seasonal variation in plasma noradrenaline levels of guide dog candidates in the advanced class. The statistical significance of differences between January and August was tested using paired t-test. $n=4$ in each group. $(* P<0.05)$.

Table 1. Foods supplied to dogs in the current study

\begin{tabular}{|c|c|c|}
\hline $\begin{array}{l}\text { Calorie and } \\
\text { components }\end{array}$ & $\begin{array}{l}\text { Natural Harvest } \\
\text { Maintenance* }\end{array}$ & $\begin{array}{l}\text { Acana Pacifica } \\
\text { for dogs** }\end{array}$ \\
\hline $\begin{array}{l}\text { Metabolic calorie } \\
(\mathrm{kJ} / \mathrm{g} \text { food })\end{array}$ & 13.4 & 14.7 \\
\hline Crude protein (\% wt.) & 18 & 33 \\
\hline Crude fat (\% wt.) & 9.5 & 17 \\
\hline Crude fiber (\% wt.) & 4 & 5 \\
\hline Moisture (\% wt.) & 10 & 10 \\
\hline \multicolumn{3}{|l|}{ Minerals } \\
\hline Magnesium (\% wt.) & 0.1 & 0.1 \\
\hline Calcium (\% wt.) & 1.6 & 1.5 \\
\hline Sodium (\% wt.) & 0.36 & 0.6 \\
\hline Chloride (\% wt.) & 0.57 & 1.1 \\
\hline Potassium (\% wt.) & 1.0 & 1.0 \\
\hline Iron (mg/kg food) & 265 & 170 \\
\hline Zinc (mg/kg food) & 404 & 230 \\
\hline Copper (mg/kg food) & 23.8 & 20 \\
\hline $\begin{array}{l}\text { Manganese }(\mathrm{mg} / \mathrm{kg} \\
\text { food) }\end{array}$ & 51.2 & 23 \\
\hline Iodine (mg/kg food) & 4.6 & 1.8 \\
\hline $\begin{array}{l}\text { Selenium (mg/kg } \\
\text { food) }\end{array}$ & 0.34 & 1.5 \\
\hline
\end{tabular}

*Natural Harvest was given to guide dog candidates and guide dogs for the blind. ${ }^{* *}$ Acana Pacifica was given to laboratory dogs used in the treadmill experiment.

In the previous studies, it mentioned that intravenous injection of adrenaline decreased blood levels of $\mathrm{Mg}^{2+}$ in humans (Joborn et al., 1985) and ewes (Rayssiguier, 1977), and that the consequent increase in adrenaline induced magnesium loss (Seelig, 1994). Therefore, we examined adrenaline and noradrenaline levels in winter and summer (Fig. 1b, Fig. 1c). Plasma adrenaline and noradrenaline levels were higher in winter; on the other hand, they became lower in summer, showing the inverse correlation with serum $\mathrm{Mg}^{2+}$ levels.
Experiment 2; Serum $\mathrm{Mg}^{2+}$ levels of guide dog candidates in different training phases

To investigate serum $\mathrm{Mg}^{2+}$ levels of dogs exposed to different amounts of external stress, we selected dogs in elementary, intermediate, and advanced training classes. These different training stages were classified according to the total of training hours and days. Serum samples were collected from May to August and $\mathrm{Mg}^{2+}$ levels were measured. The steady state levels of serum $\mathrm{Mg}^{2+}$ of dogs in elementary, intermediate, and advanced classes were $13.0 \pm 0.3 \mu \mathrm{g} / \mathrm{mL}$ (the median is $13.0 \mu \mathrm{g} / \mathrm{mL}$ ), $19.3 \pm 0.9 \mu \mathrm{g} / \mathrm{mL}$ (the median is 19.9 $\mu \mathrm{g} / \mathrm{mL}$ ), $21.5 \pm 0.5 \mu \mathrm{g} / \mathrm{mL}$ (the median is $21.7 \mu \mathrm{g} / \mathrm{mL}$ ), respectively. Serum $\mathrm{Mg}^{2+}$ levels were lower in dogs in the elementary class than those of dogs in other classes (Fig. 2).

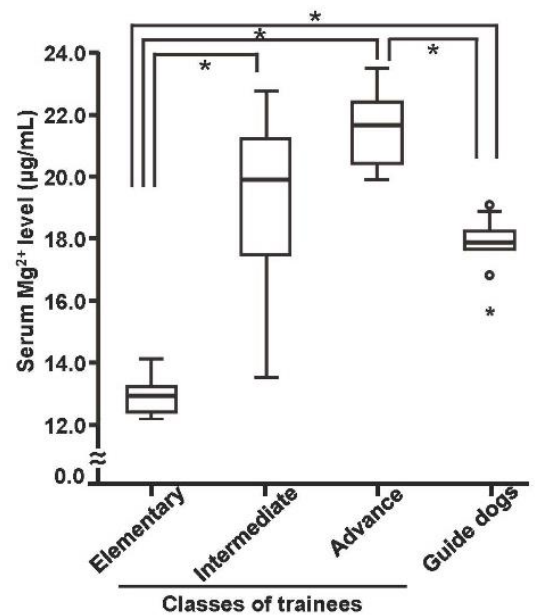

Fig. 2. Serum $\mathrm{Mg}^{2+}$ levels of guide dog candidates in different stages of training. The medians of serum $\mathrm{Mg}^{2+}$ levels measured in samples collected from May to August are indicated by the bar within each box. The statistical significance of differences between classes was tested using a one way ANOVA Dunnet. Elementary class, $n=6$; intermediate class, $n=10$; advanced class, $n=8$; healthy adult guide dogs for the blind, $\mathrm{n}=14$. $(* \mathrm{P}<0.05)$.

On the other hand, serum $\mathrm{Mg}^{2+}$ levels were significantly higher in dogs in the advanced class comparing to those of dogs in the elementary class (Fig. 2). Interestingly, serum $\mathrm{Mg}^{2+}$ levels of dogs in the intermediate class showed intermediate levels with some variation (Fig. 2).

Serum $\mathrm{Mg}^{2+}$ levels of working guide dogs for the blind were markedly higher than those of guide dog candidates in the elementary class, but lower than those of dogs in the advanced class. The right column of Fig. 2 shows the serum $\mathrm{Mg}^{2+}$ levels of healthy guide dogs for the blind without any clinical abnormalities. The serum samples were collected in May. Serum $\mathrm{Mg}^{2+}$ levels of mature guide dogs for the blind were $17.8 \pm$ $0.7 \mu \mathrm{g} / \mathrm{mL}$ (the median is $17.9 \mu \mathrm{g} / \mathrm{mL}$ ), and no individual differences were observed. 
Means of serum $\mathrm{Mg}^{2+}$ levels of each group with or without breakfast were $17.5 \pm 0.4 \mu \mathrm{g} / \mathrm{mL}$ and $17.9 \pm 0.3$ $\mu \mathrm{g} / \mathrm{mL}$ respectively, and there was no the statistical significant difference $(\mathrm{t}=-0.676, \mathrm{df}=12, \mathrm{p}>0.05)$. In the mature guide dogs, the $\mathrm{Mg}^{2+}$ value of female dogs was $17.7 \pm 0.4 \mu \mathrm{g} / \mathrm{mL}$ and that of male dogs was 17.9 $\pm 0.3 \mu \mathrm{g} / \mathrm{mL}$, and no significant difference due to the distinction of sex was observed $(\mathrm{t}=0.456, \mathrm{df}=12, \mathrm{p}>$ $0.05)$. All dogs used were clinically healthy throughout the experiment 1 and 2.

Experiment 3; Serum $\mathrm{Mg}^{2+}$ levels after exercise loads To investigate the effect of physical exercise on serum $\mathrm{Mg}^{2+}$ levels, dogs were subjected to forced exercise using a treadmill for $20 \mathrm{~min}$ in the morning, and $\mathrm{Mg}^{2+}$ levels were measured in January (winter) and August (summer).

As shown in Fig. 3, serum $\mathrm{Mg}^{2+}$ levels of dogs after forced exercise were significantly lower than those of dogs before exercise in both January (before; $16.6 \pm 0.4$ $\mu \mathrm{g} / \mathrm{mL}$ and after; $10.8 \pm 0.4 \mu \mathrm{g} / \mathrm{mL}$ ) and August (before; $18.2 \pm 0.5 \mu \mathrm{g} / \mathrm{mL}$ and after; $12.5 \pm 0.5 \mu \mathrm{g} / \mathrm{mL}$ ). All dogs used were clinically healthy throughout the experiment 3 .

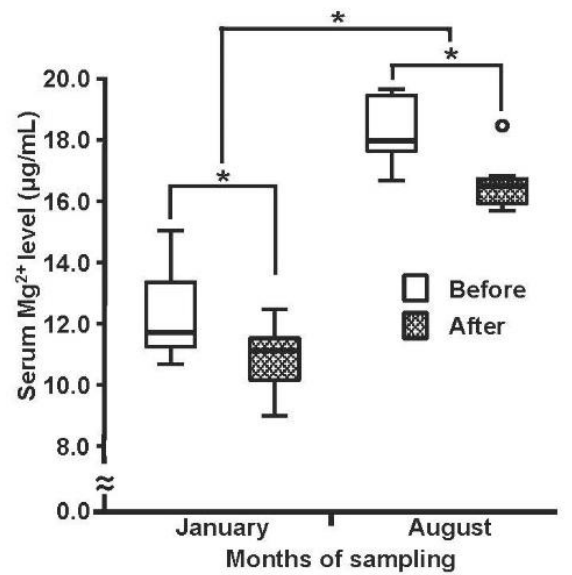

Fig. 3. Serum $\mathrm{Mg}^{2+}$ levels before and after treadmill exercise in winter and summer. The medians of serum $\mathrm{Mg}^{2+}$ levels of each group of dogs $(n=6)$ measured before and after treadmill exercise are indicated by the bar within each box. The statistical significance of differences between the each groups were analyzed using a two-way ANOVA withinparticipant design $(\mathrm{P}<0.05)$.

\section{Discussion}

Recently, decrease in blood $\mathrm{Mg}$ concentrations has been reported to associate with urinary $\mathrm{Mg}$ excretion (Disashi et al., 1996; Nielsen and Lukaski, 2006; Belluci et al., 2011). Moreover, abnormalities in $\mathrm{Mg}$ concentrations in both blood and urine have been identified in patients with neoplastic disorders (Wilhelm et al., 2002) and athletes (Nuviala et al., 1999; Nielsen and Lukashi, 2006), proposing the significance of $\mathrm{Mg}$ supplementation in some cases (Haymes, 1991; Bazzarre et al., 1993; Toba et al. 2000;
Volpe, 2015). Although dogs have long history as good partners of humans, we found very few report on changes in $\mathrm{Mg}$ concentrations of dogs induced by external stress. In the current study, we focused on serum $\mathrm{Mg}^{2+}$ levels as one of biomarkers fluctuated by external stress. Since examination of urine during dogs' training or working without contamination was quite difficult, we tried to evaluate serum $\mathrm{Mg}^{2+}$ levels before and after external stress.

First, by using young-adult guide dog candidates, we measured serum $\mathrm{Mg}^{2+}$ levels of dogs in January (winter), May (spring), and August (summer) to check seasonal changes. Serum $\mathrm{Mg}^{2+}$ levels were lower in winter; on the other hand, they became higher in summer. In previous research on humans, blood $\mathrm{Mg}^{2+}$ levels became lower in winter because the $\mathrm{Mg}^{2+}$ content of food was decreased during this season (Owaki et al., 1996). Dogs used in our study were the same breed, fed with the same dog food throughout the year in the quite similar environment. Therefore, the observed reduction in serum $\mathrm{Mg}^{2+}$ levels of dogs in winter is likely to have been caused by the effects of climatic changes, such as low temperature and the atmospheric pressure fluctuation, rather than the content of their diet. Since mammals need to maintain their body temperature during the winter, $\mathrm{Mg}^{2+}$ may be important for sustaining metabolic processes including enzymatic reactions.

Adrenaline decreased blood levels of $\mathrm{Mg}^{2+}$ in humans (Joborn et al., 1985) and exes (Rayssiguier, 1977), and induced magnesium loss (Seelig, 1994). Moreover, in humans, plasma free normetanephrine levels were higher in winter than summer (Pamporaki et al., 2014). Therefore, we checked levels of catecholamines and found that plasma adrenaline and noradrenaline levels were higher in winter than summer. Inversely, serum $\mathrm{Mg}^{2+}$ levels were higher in summer than winter, suggesting a possibility that the seasonal changes of serum $\mathrm{Mg}^{2+}$ levels were influenced by the increase in adrenaline and noradrenaline concentrations due to vasoconstriction and vasodilation in winter (Bolli et al., 1984).

Next, we measured serum $\mathrm{Mg}^{2+}$ levels of guide dog candidates at different stages in their training in order to evaluate the effects of mental and physical stress. Interestingly, serum $\mathrm{Mg}^{2+}$ levels were higher in dogs of the advanced class, compared to that of the elementary and intermediate classes. Since $\mathrm{Mg}^{2+}$ is necessary to protect individuals from environmental, physical, and mental stress (Golf et al., 1998; Soldatovic et al., 1998; Zieba et al., 2000), $\mathrm{Mg}^{2+}$ might have been applied to biologic reaction of cells and tissues in dogs in the elementary class, leading to the reduction of serum $\mathrm{Mg}^{2+}$ levels observed. In contrast, since dogs in the advanced class were accustomed to their situation, $\mathrm{Mg}^{2+}$ might have been maintained at a higher level. The 
average serum $\mathrm{Mg}^{2+}$ level of healthy adult guide dogs for the blind was $17.8 \pm 0.7 \mu \mathrm{g} / \mathrm{mL}$. In a previous study, the mean serum $\mathrm{Mg}^{2+}$ level in adult dogs was $18.8 \pm 1$ $\mu \mathrm{g} / \mathrm{mL}$ (Bailie et al., 1988), which is similar to our finding. In addition, the normal reference range for canine serum $\mathrm{Mg}^{2+}$ described in Veterinary Drug Handbook (Plumb, 1999) and the list of a biochemical examination for dogs by LSI Medience Co. (Tokyo, Japan) is $17-27 \mu \mathrm{g} / \mathrm{mL}$. However, sex, breeds, age, and seasons when $\mathrm{Mg}^{2+}$ levels were measured were not mentioned. Since the guide dogs in the present study were fed with the same food as the guide dog candidates (Table 1), the differences between the groups have not resulted from their diet, but may have been due to the higher age of the guide dogs when compared to the guide dog candidates.

Finally, we found that the exercise load using a treadmill reduced serum $\mathrm{Mg}^{2+}$ levels of subjected dogs in both winter and summer. In experiment 3, seasonal variation between winter and summer of serum $\mathrm{Mg}^{2+}$ levels was remarkable, which is similar to results obtained in experiment 1 . Since the laboratory dogs used were all fed with the same food, as indicated in Table 1, the influence of diet on serum $\mathrm{Mg}^{2+}$ levels could be excluded. Forced exercise might reduce serum $\mathrm{Mg}^{2+}$ levels because of activation of the muscles and nerves. These results suggest that serum $\mathrm{Mg}^{2+}$ levels are influenced by external physical stress.

In the current study, we demonstrated for the first time that serum $\mathrm{Mg}^{2+}$ levels of dogs might be influenced by air temperature, environment, age, and exercise load. Serum $\mathrm{Mg}^{2+}$ levels in dogs were reduced in winter, and they became higher in summer. Serum $\mathrm{Mg}^{2+}$ levels of guide dog candidates were lower in the elementary class.

As the training proceeds, serum $\mathrm{Mg}^{2+}$ levels were increased. Serum $\mathrm{Mg}^{2+}$ levels of dogs after the forced exercise were significantly lower than those before the exercise in both winter and summer. Further experiments with more dogs must take place; however, the variation of serum $\mathrm{Mg}^{2+}$ levels of dogs may become one of biomarkers that reflect physical status of dogs.

Previous research has shown that pigs became healthier after administration of the $\mathrm{Mg}^{2+}$ supplement (O'Driscoll et al., 2013). Supplementation of $\mathrm{Mg}^{2+}$ in healthy dogs with vigorous exercise or training regimes must be discussed for animal welfare. $\mathrm{Mg}^{2+}$ supplementation may also be necessary for aged dogs and beneficial for dogs that are subjected to new environments. Moreover, in winter, $\mathrm{Mg}^{2+}$ supplementation may be needed not only for working dogs but also for companion dogs, particularly those suffering from disease.

\section{Acknowledgments}

We would like to appreciate Assoc. Prof. Hideyuki Tanaka for his advice on the statistical analysis, and thank Dr. Akira Matsuda, Dr. Kumiko Oida, Dr. Yosuke Amagai, Dr. Hyosun Jang, Dr. Saori Ishizaka, and Ms Juri Toyama (Tokyo University of Agriculture and Technology) for their supports and animal care.

This work was partially supported by a joint research grant (No. 26-619) from Tateho Chemical Industries Co., Ltd. (Hyogo, Japan).

\section{Conflict of interest}

The authors declare that there is no conflict of interest.

\section{References}

Altura, B.M. and Altura, B.T. 1981. Magnesium ions and contraction of vascular smooth muscles: relationship to some vascular diseases. Fed. Proc. 40(12), 2672-2679.

Bailie, D.S., Inoue, H., Kaseda, S., Ben-David, J. and Zipes, D.P. 1988. Magnesium suppression of early after depolarizations and ventricular tachyarrhythmias induced by cesium in dogs. Circulation 77(6), 1395-1402.

Baltaci, A.K., Mogulkoc, R. and Belviranli, M. 2013. Serum levels of calcium, selenium, magnesium, phosphorus, chromium, copper and iron-their relation to zinc in rats with induced hypothyroidism. Acta Clin. Croat. 52, 151-156.

Bazzarre, T.L., Scarpino, A., Sigmon, R., Marquart, L.F., Wu, S.M. and Izurieta, M. 1993. Vitaminmineral supplement use and nutritional status of athletes. J. Am. Coll. Nutr. 12(2), 162-169.

Belluci, M.M., Gior, G., del Barrio, R.A., Pereira, R.M., Marcantonio, E. Jr. and Orrico, S.R. 2011. Effects of magnesium intake deficiency on bone metabolism and bone tissue around osseointegrated implants. Clin. Oral Implants Res. 22(7), 716-721.

Bohl, C.H. and Volpe, S.L. 2002. Magnesium and exercise. Crit. Rev. Food Sci. Nutr. 42(6), 533-563.

Bolli, P., Erne, P., Ji, B.H., Block, L.H., Kiowski, W. and Buhler, F.R. 1984. Adrenaline induces vasoconstriction through post-junctional alpha 2 adrenoceptors and this response is enhanced in patients with essential hypertension. J. Hypertens. Suppl. 2(3), S115-118.

Cowan, J.A. 2002. Structural and catalytic chemistry of magnesium-dependent enzymes. Biometals. 15(3), 225-235.

Disashi, T., Iwaoka, T., Inoue, J., Naomi, S., Fujimoto, Y., Umeda, T. and Tomita, K. 1996. Magnesium metabolism in hyperthyroidism. Endocr, J. 43(4), 397-402.

Dominguez, L.J., Barbagallo, M., Sowers, J.R. and Resnick, L.M. 1998. Magnesium responsiveness to insulin and insulin-like growth factor $I$ in erythrocytes from normotensive and hypertensive subjects. J. Clin. Endocrinol. Metab. 83, 4402-4407.

Durlach, J., Durlach, V., Bac, P., Rayssiguier, Y., Bara, M. and Guiet-Bara, A. 1993. Magnesium and 
ageing II. Clinical data: aetiological mechanisms and pathophysiological consequences of magnesium deficit in the elderly. Magnes. Res. 6(4), 379-394.

Eby, G.A. and Eby, K.L. 2006. Rapid recovery from major depression using magnesium treatment. Med. Hypotheses 67(2), 362-370.

Elin, R.J. 1988. Magnesium metabolism in health and disease. Dis. Mon. 34(4), 161-218.

Golf, S.W., Bender, S. and Gruttner, J. 1998. On the significance of Magnesium in extreme physical stress. Cardiovasc. Drugs Ther. 12(2), 197-202.

Haymes, E.M. 1991. Vitamin and mineral supplementation to athletes. Int. J. Sport Nutr. 1(2), 146-169.

He, K., Liu, K., Daviglus, M.L., Morris, S.J., Loria, C.M., Van Horn, L., Jacobs D.R. and Savage, P.J. 2006. Magnesium intake and incidence of metabolic syndrome among young adults. Circulation 113(13), 1675-1682.

He, Y., Yao, G., Savoia, C. and Touyz, R.M. 2005. Transient receptor potential melastatin 7 ion channels regulate magnesium homeostasis in vascular smooth muscle cells: Role of angiotensin II. Circ. Res. 96(2), 207-215.

Jacka, F.N., Overland, S., Stewart, R., Tell, G.S., Bjelland, I. and Mykletun, A. 2009. Association between magnesium intake and depression and anxiety in community-dwelling adults: the Hordaland Health Study. Aust. N. Z. J. Psychiatry 43(1), 45-52.

Joborn, H., Akerstrom, G. and Ljunghall, S. 1985. Effects if exogenous catecholamines and exercise on plasma magnesium concentrations. Clin. Endocrinol. 23(3), 219-226.

Lukaski, H.C. and Nielsen, F.H. 2002. Dietary Magnesium Depletion Affects Metabolic Responses during Submaximal Exercise in Postmenopausal Women. J. Nutr. 132(5), 930-935.

Nielsen, F.H. and Lukaski, H.C. 2006. Update on the relationship between magnesium and exercise. Magnes. Res. 19(3), 180-189.

Nuviala, R.J., Lapieza, M.G. and Bernal, E. 1999. Magnesium, Zinc, and copper status in women involved in different sports. Int. J. Sport Nutr. 9(3), 295-309.

O’Driscoll, K., O’Gorman, D.M., Taylor, S. and Boyle, L.A. 2013. The influence of a magnesium-rich marine extract on behaviour, salivary cortisol levels, and skin lesions in growing pigs. Animal 7(6), 1017-1027.

Owaki, A., Takatsuka, N., Kawakami, N. and Shimizu, H. 1996. Seasonal Variations of Nutrient Intake Assessed by 24-Hour Recall Method. J. Nutr. 54(1), $11-18$.

Pamporaki, C., Bursztyn, M., Reimann, M., Ziemssen,
T., Bornstein, S.R., Sweep, F.C., Timmers, H., Lenders, J.W. and Eisenhofer, G. 2014. Seasonal variation in plasma free normetanephrine concentrations: implications for biochemical diagnosis of pheochromocytoma. Eur. J. Endocrinol. 170(3), 349-357.

Pfeiffer, C.C. and Barnes, B. 1981. Role of zinc, manganese, chromium, and vitamin deficiencies in birth defects. Int. J. Environ. Stud. 17(1), 43-56.

Plumb, D.C. 1999. Veterinary drug handbook, Third Edition. Iowa State Press, Ames, Iowa, USA, pp: 812.

Rayssiguier, Y. 1977. Hypomagnesemia resulting from adrenaline infusion in ewes: its relation to lipolysis. Horm. Metab. Res. 9(4), 309-314.

Resnick, L.M., Oparil, S., Chait, A., Haynes, R.B., Kris-Etherton, P., Stern, J.S., Clark, S., Holcomb, S., Hatton, D.C., Metz, J.A., McMahon, M, PiSunyer, F.X. and McCarron, D.A. 2000. Factors affecting blood pressure responses to diet: the Vanguard study. Am. J. Hypertens. 13(9), 956-965.

Rude, R.K. and Gruber, H.E. 2004. Magnesium deficiency and osteoporosis: Animal and human observations. J. Nutr. Biochem. 15(12), 710-716.

Seelig, M. and Altura, B.M. 1997. How best to determine magnesium requirement: need to consider cardiotherapeutic drugs that affect its retention. J. Am. Coll. Nutr. 16(1), 4-6.

Seelig, M.S. 1994. Consequences of magnesium deficiency on the enhancement of stress reactions; preventive and therapeutic implications. J. Am. Coll. Nutr. 13(5), 429-446.

Sinert, R., Spektor, M., Gorlin, A., Doty, C., Rubin, A., Altura, B.T. and Altura, B.M. 2005. Ionized magnesium levels and the ratio of ionized calcium to magnesium in asthma patients before and after treatment with magnesium. Scand. J. Clin. Lab. Invest. 65(8), 659-670.

Singh, R.B., Beegom, R., Rastogi, S.S., Gaoli, Z. and Shoumin, Z. 1998. Association of low plasma concentrations of antioxidant vitamins, magnesium and zinc with high body fat percent measured by bioelectrical impedance analysis in Indian men. Magnes. Res. 11(1), 3-10.

Singh, R.B., Niaz, M.A., Moshiri, M., Gaoli, Z. and Shoumin, Z. 1997. Magnesium status and risk of coronary artery disease in rural and urban populations with variable magnesium consumption. Magnes. Res. 10(3), 205-213.

Soldatovic, D., Matovic, V., Vujanovic, D. and Stojanovic, Z. 1998. Contribution to interaction between magnesium and toxic metals: the effect of prolonged cadmium intoxication on magnesium metabolism in rabbits. Magnes. Res. 11, 283-288.

Soria, M., Gonzalez-Haro, C., Anson, M.A., Inigo, C., Calvo, M.L. and Escanero, J.F. 2014. Variations in 
serum magnesium and hormonal levels during incremental exercise. Magnes. Res. 27(4), 155-164.

Toba, Y., Kajita, Y., Masuyama, R., Takada, Y., Suzuki, K. and Aoe, S. 2000. Dietary magnesium supplementation affects bone metabolism and dynamic strength of bone in ovariectomized rats. $\mathbf{J}$. Nutr. 130(2), 216-220.

Tucker, K.L., Hannan, M.T., Chen, H., Cupples, L.A., Wilson, P.W. and Kiel, D.P. 1999. Potassium, magnesium, and fruit and vegetable intakes are associated with greater bone mineral density in elderly men and women. Am. J. Clin. Nutr. 69(4),
727-736.

Volpe, S.L. 2015. Magnesium and the Athlete. Curr. Sports Med. Rep. 14(4), 279-283.

Wilhelm, Z., Kleinova, J. and Kalábová, R. 2002. Effect of magnesium administration on urinary ion excretion in healthy subjects and cancer patients. Scr. Med. (Brno). 75(5), 231-238.

Zieba, A., Tata, R., Dudek, D., Schlegel-zawadzka, M. and Nowak, G. 2000. Serum trace elements in animal models and human depression: Part III. Magnesium. Relationship with copper. Hum. Psychopharmacol. 15(8), 631-635. 